\title{
Natural Disaster and Heritage Tourism: A Study on the Impacts of Earthquake in Bhaktapur, Nepal
}

\author{
Ramesh Raj Kunwar * \\ Usha Chand**
}

"Our future is where our past is" (Katriel, 1993)

\begin{abstract}
The article reviews on the complex and intricate linkages between heritage and tourism, highlighting the importance of the heritage industry and the vulnerability the industry can face when confronted with a natural disaster such as earthquake. The article aims not just to introduce the Kathmandu Valley in the light of the seven World Heritage Sites but also aims to prioritize the devastation that the recent earthquake brought upon the 'Living Heritage', Bhaktapur. The article assesses the earthquake's impact on tourism in Bhaktapur and finally sheds light upon the tourism recovery process that is undergoing along with the issues of heritage reconstruction with a comparison on what has been done and what has to be done for the overall purpose of tourism recovery.
\end{abstract}

Keywords: Natural disaster, safety, security, heritage, heritage tourism, recovery.

\section{Introduction}

Tourism is travel for recreation, leisure, religious, family or business purposes, usually for a limited duration. Tourism has become a popular global leisure activity and a major source of income for many countries, affecting the economy of both the source and host countries. Tourism cannot provide employment and income to all the people in a destination and hence it cannot be a panacea for economic development but Kunwar (2012) states that 'as a labor intensive service industry, tourism has the

\footnotetext{
* Prof. Dr. Ramesh Raj Kunwar is the author of seven books on tourism and anthropology. He is tourism educationist and anthropologist by profession. He is the former Dean of Faculty of Humanities and Social Sciences, Tribhuvan University, Kathmandu, Nepal. He is also the former Dean of (then) Royal Nepalese Military Academy. Currently, he is teaching at the Department of Cunflict, Peace and Development Studies (DCPDS), T.U. Email: kunwardr@gmail.com

** Usha Chand is doing research on natural disaster and heritage tourism in Bhaktapur.
} 
capacity to create jobs for large numbers of people of varying levels of skills, from top level executives to the semi-skilled and unskilled'. Tourism can help the poor improve their livelihoods, but this will require concerted efforts - strategies that help establish strong linkages with the tourism sector (Baskota \& Sharma, 1996).

Enjoyment, pleasure, relaxation and safety are embodied in the concept of tourism whereas crisis/disasters bring distress, fear, anxiety, shock, trauma and panic (Santana, 2009: 300; in Kunwar, 2012). A disaster occurs when a significant number of vulnerable people experience a hazard and suffer severe damage and/or disruption of their livelihood system in such a way that recovery is unlikely without external aid. Disaster, as such, is a result of the interaction of hazard and vulnerability. 'Hazard' refers to the natural events that may affect different places singly or in combination at different times and 'vulnerability' refers to the potential for casualty, destruction, damage, disruption or other form of loss in a particular element: risk combines this with the probable level of loss to be expected from a predictable magnitude of hazard (Wisner et al., 2003: 49-50).

When we talk about disaster, a disaster is a natural or man-made event that negatively affects life, property, livelihood or industry often resulting in permanent changes to human societies, ecosystems and environment. Natural Disaster is a sudden, catastrophic event that causes serious commotion of the functioning of a community or a society causing widespread human, material, economic and environmental losses which exceed the ability of the affected community or society to cope seeing its own level of resources. For instance it destroys the natural surroundings and resources which the industry depends on. Natural disasters come in so many ways and forms. Examples are earthquake, flood, volcanic eruption, tornado, tsunami, wildfire, drought, hailstorm, heatwave, hurricane, epidemic, famine, mud flow, solar flare and other disasters (Hamzah et al., 2012).

Our focus here, is upon earthquake among various other natural disasters because even after years of an event of earthquake, the impact can still be felt upon the tourists' trip decision such as Taiwan's earthquake of September 21, 1999 (dubbed as 921) (Huan, Beaman \& Shelby, 2004). An earthquake is a sudden and unpredictable movement of the Earth's crust caused by release of strain that has accumulated over a long time. An earthquake belongs to the most devastating natural disasters. Earthquakes may cause many deaths, injuries and extensive property damage often triggering avalanches, rock falls and tsunamis (Park \& Reisinger, 2010:6; in Kunwar, 2015:20). Earthquakes by themselves rarely kill people or wildlife. It is usually the secondary events that they trigger, such as building collapse, fires, tsunamis (seismic sea waves) and volcanoes that are actually the human disaster. Many of these could possibly be avoided by better construction, safety systems, early warning and planning (Davis, 2009). 
While disaster is a situation in which a tourism destination is confronted with sudden, unpredictable, catastrophic changes over which it has little control (Faulkner \& Russell, 2001), a crisis is a situation requiring radical management action in response to events beyond the internal control of the organization, necessitating urgent adaptation of marketing and operational practices to restore the confidence of employees, associated enterprises and consumers in the viability of the destination (Beirman, 2003:4). Though generally taken negatively, Faulkner (2001:137) argues that crises and disasters have transformational connotations with each such event having potential positive as well as negative outcomes. Berman and Roel (1993:82; in Faulkner, 2001:137) state that crises bring about marked regressions as well as opportunities for creativity and new options.

The major determinant in a traveler's decision to visit a destination is the perception of safety and security. Thus, when any natural disaster occurs, these very notions of safety and security in the destination are questioned. Global leisure tourism tends to be focused on the region described aptly by tourism academics as the "pleasure periphery". Many of the "pleasure periphery" destinations also happen to be located in regions subject to earthquake and volcanic activity. The global tourism industry is however becoming increasingly resilient to both natural and manmade threats. For this, the effective management of natural disasters has to be done. The effective management of natural disasters is enacted in four phases: readiness, reduction, response and recovery. The development of a close working relationship between tourism government authorities, businesses and emergency management agencies is integral to minimizing the impact of any natural disaster on a tourism business or destination (Beirman, 2012).

Gilbert (1990) analyses the various demands that a tourist may have from a destination area. These demands are attractions, heritage, sport activity, entertainment, relaxation, health, shopping, and business activities. Out of these, cultural heritage, as put forward by Timothy (2011), is one of the most fragile resources upon which tourism can be based and must be managed with utmost care so that it remains viable for generations to come.

The word 'heritage' in its broader meaning is frequently associated with the word 'inheritance', that is, something transferred from one generation to another. Barbara Kirshenblatt-Gimblett (1998: 7) describes heritage as "a mode of cultural production in the present that has recourse to the past," as a specific way of interpreting and utilizing bygone times that links individuals with a larger collective(Hoelscher, 2006: 200). Heritage, as Hoelscher (2006) states, "is not merely a way of looking at the past, but a force of the present that affects the future." As Lowenthal stresses, understanding heritage is crucial; 'we learn to control it lest it control us' (Lowenthal, 1998: 3; in Harvey, 2001:338). The role of heritage as a carrier of historical value from 
the past means that it is seen as part of the cultural tradition of society. The concept of 'tourism', in contrast, is a form of modern consciousness: 'Tourism's fundamental nature is dynamic, and its interaction with heritage often results in a reinterpretation of heritage. In its essence, the relationship between heritage and tourism parallels the debate that takes place within a society's culture between tradition and modernity' (Nuryanti, 1996:250).

Heritage means 'anything you want' in this new era of insatiable obsession with the past (Hewison, 1987:32; in Park, 2014:7). Within the context of tourism development, Nuryanti (1996; in Park, 2014:25) groups heritage into three main categories: built heritage that can be described as historic and artistic heritage such as relics, forts and modern towns; scientific heritage encompasses elements such as plants, birds, animals, rocks and natural habitats; and cultural heritage comprises folk and fine arts, customs and languages. Park (2014) views heritage as a symbolic embodiment of the past, reconstructed and reinterpreted in the collective memories and traditions of contemporary societies rather than being perceived as a mere apotheosis of bygone times. Thus, heritage is culturally ascribed and socially constructed and is a flexible concept where heritage today, is related with the increasing contemporary use of the past, as manifested in the popularity of a 'heritage industry'.

Heritage encompasses a wider scope of meanings ranging from cultural and historical significances, political implications, spiritual and intellectual connotations to communications. Di Giovine (2009:91; in Park, 2014:7) highlights that depending on its usage, heritage can determine personal property, explicate unknown qualities, foster patriotism among disparate people, become a tourist destination, exacerbate geopolitical tensions, or call for help in the form of preservation, among other usages. For Park (2014), understanding heritage as a concept whose meanings vary depending on the context and over time in particularly applicable in relating heritage to tourism contexts. Thus, heritage ceases to be a static outcome of the past, particularly when it is presented and represented in the context of tourism. This is also because heritage is constantly reconstructed and reinterpreted in an attempt to meet the specific demands of tourists and reflect the socio-cultural changes of the contemporary world.

First, heritage might look old-after all, the language of heritage focuses on preservation, revitalization, and restoration-but closer inspection usually reveals contemporary concerns. Lurking just below the surface of the reclamation of a heritage are the needs, the interests, and affairs of a present generation (Glassberg, 2001; in Hoelscher, 2006: 206). Second, and just as revealing, is the processual nature of heritage, a social process that is continually unfolding, changing, and transforming. Commemorative activities, especially those involving the establishment of historic museums or monuments, attempt to stabilize and clarify the past that remains elusive. History, as it has been traditionally written, might follow chronology, but 
time's passage is never so neatly define in heritage, where time is the target of strategic rearrangement (Hoelscher, 2006: 206).

Among current scholars, the work of French historian Pierre Nora (1989) has been especially influential in establishing the connection between heritage and place. His notion of "sites of memory" - or lieux de memoire-gives prominent attention to the various way in which heritage is spatially constituted. For Nora, heritage is attached to "sites" that are concrete and physical-the burial places, cathedrals, battlefields, prisons that embody tangible notions of the past-as well as to "sites" that are nonmaterial-the celebrations, spectacles and rituals that provide and aura of the past (Hoelscher, 2006: 204).

According to Salazar (2010:130; in Park. 2014:3), on the domestic level, cultural heritage is commonly used to stimulate pride in the (imagined) national history or to highlight the virtues of particular ideologies. In the supranational sphere, heritage sites are marketed and sold as iconic markers of a local area, country, region or even continent, and the journey abroad as an opportunity to learn about the 'Other'-some go as far as promising a contribution to worldwide peace and understanding.

Tourism has been as an opportunity and also as a threat to heritage. Heritage tourism is becoming an increasingly significant component of the global tourism industry and the growth of the heritage industry has undoubtedly contributed to expanding the scope and appeal of heritage. Thus, the commodification in heritage has led to creating and fabricating a new environment in which different possibilities and potentials of heritage can coexist for different audience. Within the context of tourism development, heritage often becomes a commercially driven entity that is carefully selected, packaged and promoted (Park, 2014).

Heritage tourism is concerned with exploring both material and immaterial, i.e., tangible and intangible remnants of the past. Heritage tourism is at present largely characterized by an expanding range of concepts and definitions, by a mix of individual case studies and more general discourses (Balcar \& Pearce, 1996:203). Heritage tourism is a phenomenon based on tourists' motivations and perceptions rather than on specific site attributes. It is a subgroup of tourism, in which the main motivation for visiting a site is based on the place's heritage characteristics according to the tourists' perception of their own heritage (Poria et al., 2001:1048). Heritage tourism is an idea compounded of many different emotions, including nostalgia, romanticism, aesthetic pleasure and a sense of belonging in time and space (Ashworth \& Goodall, 1990:162).

Peterson (1994:121) stated that 'we think of heritage tourism as visiting of areas, which make the visitor think of an earlier time'. Zeppel and Hall (1992:78) also supported the concepts of 'nostalgia' and of 'special form of tourism', noting that 
'heritage tourism is a broad field of specialty travel, based on nostalgia for the past and the desire to experience diverse cultural landscapes and forms'.

The term 'heritage and cultural tourism' refers to that segment of the tourism industry that places special emphasis on heritage and cultural attractions. These attractions are varied, and include performances, museums, displays, archaeological sites and the like. In developed areas, heritage and cultural attractions include art museums, plays, and orchestral and other musical performances. Tourists may travel to specific sites to see a famous museum or to hear a special musical performance. In less developed areas, heritage and cultural attractions may include traditional religious practices, handicrafts and cultural performances. In this regard, Smith (1999:32; in Fernandes, 2013:28) highlights, Culture has always been a major object of travel. Actually, nowadays, tourism is culture. Because of the increasing pace of life people have turned to the preservation of the past. It seems that the combination of nostalgia for the past, the need to reassert national and local identities and the perceived economic benefits of cultural development have had a dramatic effect on the supply of cultural attractions.

Apostolakis (2003:795-796) argues that heritage tourism is currently experiencing a transformation from Fordist to Post-Fordist operations. Fordism includes mass produced, standardized tourism packages aiming to the mainstream market focusing upon sun, sea and sand whereas, Post-Fordist operations meant the diversion from sun and sea holiday towards more sophisticated types of vacations where exclusivity, differentiation, and unique personal experiences are more focused. Therefore, heritage today, is a contemporary commodity created to satisfy contemporary consumption.

Due to the wide array of attractions and tourist products that heritage tourism offers Timothy (2011) states that heritage tourism is highly inclusive- probably the most encompassing type of tourism yet to be identified. It revolves directly around living cultures, the built environment, faith, traditions, folklore, arts and handicrafts, music and the everyday life of people. Ethnic tourism, cultural tourism, religious tourism and industrial tourism fit snuggly under the heritage tourism umbrella. Even sports tourism, shopping tourism, agritourism, volunteer tourism, wine tourism, educational travel and health tourism overlap a great deal with heritage tourism.

Richards (1996b: 21; in Apostolakis, 2003: 801) puts forward his view that culture and heritage as a process will appeal to tourists seeking authenticity and meaning through their tourist experiences. Authenticity means truth, central of the ultimate "truths" that modern tourists search for outside of their rather superficial home lives (Kunwar, 2002: 117-121; in Kunwar, 2012: 135). Kunwar also stresses that authenticity 
refers to another kind of truth, it means that things really are what they are said to be the opposite of authenticity is not "new" or "souvenir" but "fake" or "misrepresented", though these two often go together under the influence of commercialism.

Prentice (1993) stated that heritage tourists and visitors could be divided into five predominant groups: (1) educated visitors; (2) professionals; (3) families or groups; (4) schoolchildren; and (5) nostalgia seekers. However, Chen's (1996) research found that there was a highly insignificant relationship between educational attainment and reason for visiting a heritage site. Whatever the case may be, heritage tourism can be one of the most important sources of income to the local community and also a source for improving their livelihood. Part of this has been explained by Timothy (2011) where he states that heritage tourists are more likely to shop while travelling than many other types of tourists. He also states that cultural tourists have a keener interest in taking home a momento of what they have seen. Thus, museum and heritage sites now play into this truism by offering on-site shopping. This brings extra revenue to help meet the conservation goals of the site.

Out of the various types of natural disasters, earthquakes are one of those which cannot be prevented and whose impacts can be catastrophic. Beirman (2003) while analyzing the Izmit earthquake of 1999 in Turkey found out that while the human cost of the earthquake was massive, the financial cost all but crippled the Turkish economy, which had been burdened by $50 \%$ per annum inflation, massive external debt and a government hampered by ongoing deficit budgeting. The media coverage at the time of the quake painted a picture of Turkish devastation reducing the tourist numbers to $-23.5 \%$ than the previous year.

But the recovery of Turkey's tourism industry was one of the most rapid and complete marketing restoring campaigns involving a well co-ordinated marketing campaign combining the resources of the government and the private sector. Kunwar \& Limbu (2015) state that the lesson that Nepal can learn from Turkey's case is how to proactively deal with potential for future crisis related to tourism.

The negative consequences of these incidents can thus, be moderated if the stakeholders involved in tourism industry get prepared for confronting such incidents. But, as Drabek (1995) and Prideaux et al. (2003) note, crisis preparation is not yet an integral component of tourism business practice, and many tourism executives seem reluctant to anticipate the need. So, the need for crisis preparedness is obvious. Kovoor - Misra (1995) defines crisis preparation as an ongoing process of developing organizational capabilities to prevent, contain and recover from crises, and to learn from experience. Furthermore, Siomkos and Maditinos (2001) support that preparation is very important for organizations involved in high risk business activities like airlines, chemical industry, coastal shipping etc. Pearson (2002) identifies 
the obvious: there is no way to ensure that an organization will escape crises. The only way for an organization to minimize crisis damage is either to avert crisis if possible or to manage it effectively. This can be achieved by being as best prepared as possible. Crisis preparation should be of high concern for every business involved in tourism industry.

The destination should exercise damage control at the time of the negative event. This includes activities such as: monitoring and managing media coverage; conducting background briefing for journalists, key tourism players, tour operators and travel agents; limiting harm to tourists already on location; restricting damage to tourism infrastructure and showing tourism service operating normally; seeking assurances from source governments that they will support a destination's attempts to control the problems and the image damage resulting (Kunwar, 2012).

Coping with a crisis situation thus, requires a crisis management plan. Crisis management can be defined as an ongoing integrated and comprehensive effort that- organizations effectively put into place in an attempt to first and foremostunderstand and prevent crisis, and to effectively manage those that occur, taking into account each and every step of their planning and training activities, the interest of their stakeholders (Santana: 2009). Crisis management is clearly a task of destination management and an important tool to enhance destination competitiveness (Pechlaner et al., 2007:169; in Kunwar, 2015:21). Though a natural disaster, the severity of it can lead an earthquake to result into a crisis situation.

The effects of a natural disaster such as earthquake upon heritage tourism will be discussed in detail later in the article; however, such disasters can damage and destroy the very foundation upon which heritage tourism rests, i. e., heritage itself. This heritage can be tangible as well as intangible. The tangible heritages include buildings, sites, landscapes, neighborhoods or perhaps some large movable objects such as trains, ships, aircrafts, or smaller artifacts such as tools, weapons or memorabilia (MorseKahn, 2011:132). The intangible cultural heritage is defined by UNESCO as "the practices, representations, expressions, knowledge, skills- as well as the instruments, objects, artefacts and cultural spaces associated therewith- that communities, groups and in some cases, individuals recognize as part of their cultural heritage".

Nickell (2011: 395) believes that culture must be conserved as we preserve only what is already dead. These heritages as such need to be preserved if heritage tourism is to be made more sustainable and viable for generations to come. In this regard, the preservation or conservation of a cultural property has been defined as including "all actions aimed at safeguarding.... for the future in order to study, record, retain and restore the culturally significant qualities of the object with the least possible intervention" (Stubbs, 2009: 21; in Ames \& Hamroun, 2011: 29). 
Preservation is defined as the act or process of applying measures necessary to sustain the existing form, integrity and materials of a historic property. Work, including preliminary measures to protect and stabilize the property, generally focuses upon the ongoing maintenance and repair of historic materials and features rather than extensive replacement and new construction (Ames et al., 2011: 41). The other more invasive treatments are restoration, rehabilitation or renovation, reconstruction, relocation and replication. Restoration returns a building, site, or work of art to an appearance it had at an earlier time. Rehabilitation makes efficient contemporary use of a property possible once again; reconstruction is the reassembly of a partially or completely collapsed structure on its original site using most if not all of its original materials. These are followed by relocation when the only way to save an old building is to move it and replication which entails making a copy of a vanished building (Ames \& Hamroun, 2011: 38).

Natural disaster such as earthquake emerge the need for reconstruction of the cultural heritage. But, reconstruction has always been one of the most controversial issues for those with an interest in the material evidence of the past. Stanley-Price (2009: 33) considers reconstruction of ruins as an extreme example of restoration. As the World heritage Operational Guidelines state, reconstruction is 'acceptable only on the basis of complete and detailed documentation and to no extent on conjecture'. Stanley-Price (2009) also argues that while reconstruction of cultural heritage can increase national symbolic value, can continue to serve the previous function of the heritage or make possible a new, different function, can be rewarding in the field of education and research, can assist in tourism promotion and site preservation; it can also cause the loss of the evocative value of ruined buildings, cause the difficulty of achieving authenticity, cause the destruction of original evidence and disruption of landscape values with the ethical issue of conveying erroneous information along with distorted site interpretation and that too at an expensive and high cost.

In most cases, the relationship between cultural heritage tourism lies near full co-operation (du Cros \& McKercher, 2002, 2015). Cultural heritage can be potentially preserved through tourism (Garrod \& Fyall, 2000). Creating a symbiotic relationship between tourism heritage preservation is the ideal relationship (Aas, Ladkin, \& Fletcher, 2005). Aas et al's (2005; in Nyaupane, 2009: 159)) study of stakeholder collaboration in managing heritage managing heritage in Luang Praban, Laos, Suggested Five major ways to achieve full collaboration in managing heritage, including establishing channels of communication, generating income for conservation, involving the local community in decision making, involving the local community in tourism activities and the extent of stakeholder collaboration. The full collaboration model is based on the assumption that heritage belongs to the community (Nyaupane, 2009: 159). 
Renfrew \& Bahn (1996: 509; in Moratto, 2011: 64) have noted that the past is a big business which is politically highly charged, ideologically powerful and significant. Heritage sites provide the tangible links between past, present and future and are the focus for the struggle between the potentially conflicting aspirations of conservation and tourism. Millar (1989) explains that heritage sites are multi-purpose providing tourist attraction, community identity, formal and informal education and economic regeneration as well. However, Millar also argues that the conflicting demands of tourism and conservation can be seen in stark contrast in developing countries. Millar (1989) stresses that that the concept of heritage management has arisen in response to the special needs of the heritage industry where heritage attractions represent irreplaceable resources for the tourism industry so conservation a vital component of their management. Heritage sites need to have their own unique attributes emphasized and the interpretation and presentation of the attraction must be such as to accommodate the needs of the visitor while at the same time, management has a responsibility to the community to preserve the site for posterity.

The review of 64 journal articles covering disaster, crises and post-disaster recovery in tourism conducted by Mair et al. (2014) show that these articles focused on issues such as 'tourism and disaster', 'destinations and disaster', 'tourism and crisis' and 'post-disaster and tourism. These articles mainly focused upon recovery at a destination level. They addressed different types of disasters such as terrorist attacks, earthquakes, bushfires, Tsunami, epidemics, pollution, etc. but none of those articles have linked and shown the relationship between natural disaster such as earthquake and heritage tourism.

Similarly, even in the field of heritage tourism, many studies have been conducted by various scholars. Park (2014), Timothy (2011), Ames \& Hamroun (2011), Apostolakis (2003), Stanley-Price (200), Moratto (2011) have all provided their findings focusing upon heritage tourism, its importance, the transformation in heritage tourism, the reconstruction of heritage, the preservation and conservation of heritage and the scope of the heritage industry. But, here as well, none have related heritage tourism with earthquake.

Thus, this study aims to be the first of its kind trying to find the linkages between natural disasters and heritage tourism.

\section{Research Methods}

This is a qualitative research. Denzin \& Lincoln (1994:2) define qualitative research as multi-method in focus, involving an interpretative, naturalistic approach to its subject matter. This research has used triangulation research methodology. Richards (2005:21) defines triangulation as an interdisciplinary approach which covers multiple methods, multiple sources of data, multiple investigators or researchers on a project 
or multiple theories or perspectives in order to analyze a single dataset. This research has used methodological triangulation which involves using more than one method to gather data and informant triangulation that gives the researcher the leverage to conduct research with various types of informants.

The use of a single coder for data collection and analysis increases trustworthiness of qualitative research. The criteria for trustworthiness according to Decrop (2004; in Mair et al., 2014) are credibility, transferability, dependability and confirmability. Credibility refers to the truthfulness of the findings of the research study. Transferability is similar to generalizability. Dependability can be considered as the correspondence between the data recorded by the recorder and what actually occurred in the datacollection-setting (Decrop, 2004; in Mair et al., 2014). Confirmability is another feature of qualitative research focused by Decrop. Confirmability (associated with objectivity) pertains to how neutral the findings are. This research has focused upon these very criteria of trustworthiness with the existing knowledge of the field possessed by the researcher, the details of the context and the logical links between those so that any other researcher repeating this research would reach similar conclusions.

The study was conducted with the tourism industry, Government stakeholders, tourists themselves as well as local residents in the affected destination. Semistructured interviews and qualitative content analysis of secondary data and literature have been focused. Thus, this is a mixed method approach.

\section{The Earthquake of April 25, 2015}

The earthquake of April 25, measuring 7.8 in the Richter scale and its subsequent aftershocks has directly shown its impact upon the entire nation. Approximately 9,000 people lost their lives and more than 22,000 people were injured. As per the latest estimates, more than half a million houses collapsed or are damaged. The earthquake lowered GDP growth by over $1.5 \%$ from an estimate of $4.6 \%$ in a noearthquake scenario in fiscal year 2015 (which ended 15 July 2015). Although the earthquake struck Nepal in the tenth month of FY2015, the impact on GDP growth is sizable especially on the services sector, which is now expected to grow by $3.9 \%$ compared to $6 \%$ in a no-earthquake scenario. Wholesale and retail trade; tourism (including air transport, and hotel and restaurant businesses); real estate, renting and business activities; and education sub-sectors are the most affected. Per capita income is estimated to decrease by USD 23 to USD 762 in FY2015 compared to the no-earthquake scenario of USD 785. Real per capita income, which takes inflation into account, is forecast to increase by just $0.6 \%$ against $3.6 \%$ had there been no earthquake (PDNA, 2015).

Thirty-one of the country's 75 districts had been affected, out of which 14 were declared 'crisis-hit' for the purpose of prioritizing rescue and relief operations; another 
17 neighboring districts are partially affected. The destruction was widespread covering residential and government buildings, heritage sites, schools and health posts, rural roads, bridges, water supply systems, agricultural land, trekking routes, hydropower plants and sports facilities (MoHA, 2015).

According to Tourist Police Unit of Nepal Police, 79 tourists were killed and 69 were missing and to worsen the situation, the national and international media coverage has highly highlighted upon the negative devastations caused by the quake leading to more negative travel advisories from various foreign Governments to their citizens (Kantipur, 4 May, 2015).

The earthquake affected about 2,900 structures with a cultural and religious heritage value. The list of damaged or destroyed structures was compiled by Ministry of Culture, Tourism and Civil Aviation (MoCTC), the Pashupati Area Development Trust, and the Buddhist Philosophy Promotion and Monastery Development Committee. Major monuments in Kathmandu's seven World Heritage Monument Zones were severely damaged and many collapsed completely. In addition, in more than 20 districts, thousands of private residences built on traditional lines, historic public buildings as well as ancient and recently built temples and monasteries were affected by the earthquakes, $25 \%$ of which were destroyed completely. The total estimated damages to tangible heritage amounts to NPRs 16.9 billion (USD 169 million) (MoCTCA, 2015).

Naya Patrika (16 February, 2016) however, writes that according to the Department of Archaeology, the earthquake has destroyed heritages worth more than 12 billion Rupees all over the country. These include 721 structures like temples and palaces that have been severely damaged, 133 structures that have been destroyed completely, 95 structures that have been rendered useless and 93 structures that have suffered partial damage.

The overall impact of the earthquake on the tourism sector goes beyond the 14 affected districts, which have suffered significant physical damage to well-known tourism destinations like Chitwan and Pokhara in terms of a sharp fall in the number of tourists. The negative repercussions of the disaster are likely to translate into a reduced number of tourist arrivals over the next few years, reduction in tourist spending per day from USD 43 to USD 35, which will significantly affect revenues. Other nations that have experienced similar disasters have generally taken several years to recover fully with regard to tourist arrivals. It is estimated that the overall impact of the earthquakes on the Nepali tourism industry will be a reduction of about 40 percent on average over the next 12 months, and a 20 percent reduction in the next 12 to 24 months (PDNA, 2015).

It is estimated that the total value of disaster effect caused by the earthquake is NPRs 706 billion where $11 \%$ of the destruction and production decline is caused 
in tourism sector. Damages equivalent to 18863 million NPRs was to be faced by tourism sector alone of Nepal (Kunwar, 2015). Thus, adopting the best practices in restoring tourism back is a must where policy level of addressing to the issue will be required.

\section{Introduction to Kathmandu Valley}

Within the relentlessly steep terrain of midland Nepal, the Kathmandu Valley is something of a geographical freak: a bowl of gently undulating, richly fertile land, lifted up towards the sky like some kind of sacrifice. It may only be some $25 \mathrm{~km}$ across, but it is densely packed with sacred sites. So much so, in fact, that well into modern times it was referred to as "Nepal mandala", implying that the entire valley acted as a gigantic spiritual diagram, or circle. "The valley consists of as many temples as there are houses", enthused William Kirkpatrick, the first Englishman to reach Kathmandu, and as many idols as there are men."

The valley is made up of the Kathmandu District, Lalitpur District and Bhaktapur District covering an area of 220 square miles(almost the area of Singapore). The valley is a cultural and political hub of Nepal. The Kathmandu valley was accorded the status of a World Heritage Site by UNESCO in the year 1979.

Despite rampant development, the valley's underlying traditions have proved remarkably resilient. It was long the stage for the quarrels of three rival city-states, Kathmandu, Patan and Bhaktapur, and these divisions remain ingrained in valley society. Kathmandu and Patan have now grown together within the confines of the Ring Road, but Bhaktapur, on the east side of the Bagmati River, still remains proudly separate. Like the other, smaller Newari towns of the valley - Kirtipur, Thimi, Sankhu, Bungmati- it preserves a distinctly medieval air, its wood- and brick-built houses tightly clustered together around alleyways and temple plazas, and the lives of its residents still bound up with the paddy fields outside the city walls. On the southern and eastern sides of the valley, meanwhile, and in the lush side-valleys and on the steep slopes of the rim, the countryside continues to shimmer in an undulating patchwork of paddy fields - brown, golden or brilliant green, depending on the crop and the season.

Among urban centres, the Kathmandu Valley is the main hub of economic activities, accounting for a whopping 23.4 percent of the national economy. The Kathmandu Valley accounts for 40 percent of the jobs generated in urban areas. 24 percent of Nepal's urban population lives in Kathmandu. Kathmandu is home to 9.72 percent of Nepal's total population (The Kathmandu Post, 14 July, 2015).

According to the 1975 survey of IUCN and Nepal Heritage Society, Kathmandu Valley has 888 heritage sites of global significance and there are 1254 heritage sites in 72 districts outside the Kathmandu Valley. 


\section{World Heritage Sites of Nepal}

A World Heritage Site is an area or place of cultural or natural significance that is deemed to have outstanding universal value and is therefore worthy of protection. That protection is made possible through the inscription by the World Heritage Committee of such a place in the World Heritage List in terms of the World Heritage Convention established in 1972 by United Nations Educational, Scientific and Cultural Organization (UNESCO). The mission of the World Heritage Convention is to encourage countries to nominate cultural and natural heritage sites for possible inclusion on the World Heritage List. It also offers assistance to countries with challenges of safeguarding their sites against threats of changing social and economic conditions and natural decay. Once a site is inscribed in the World Heritage List, it receives national and international recognition and the country is required to ensure that effective and active measures are taken for the protection, conservation and presentation of the site.

A well-targeted marketing strategy for a World Heritage Site is likely to lead to an influx of tourists to the site, contributing to economic growth and increased employment opportunities. The capacity of a country to manage this potential change and the increase in tourism in an area is one of the main criteria in the World Heritage Convention.

As far as World Heritage Sites of Nepal are concerned, there are seven sites known as Boudhanath, Changu Narayan, Hanuman Dhoka Palace (Kathmandu), Layaku Durbar Square (Bhaktapur), Mangal Bazar Durbar Square (Lalitpur), Pashupatinath and Swoyambhunath in Kathmandu Valley. There are three sites out of Kathmandu Valley. They are known as Lumbini (the birth place of Lord Buddha), Royal Chitwan National Park and Sagarmatha National Park (Kunwar, 2012:127).

\section{World Heritage Sites within the Kathmandu Valley}

The Kathmandu Valley World Heritage Site is inscribed on the UNESCO list of World Heritage as a single site comprising of seven Monument Zones. The cultural heritage of the Kathmandu Valley is illustrated by seven groups of monuments and buildings which display the full range of historic and artistic achievement for which the Kathmandu Valley is world famous. The seven include the Durbar Squares of Hanuman Dhoka (Kathmandu), Patan and Bhaktapur, The Buddhist stupas of Swayambhu and Bauddhanath and the Hindu temples of Pashupatinath and Changu Narayan (KVWHS- Integrated Management Framework, 2007:2).

The Kathmandu Valley World Heritage Site (KVWHS) was inscribed on the World Heritage List under criteria iii, iv and vi as per the UNESCO's Operational Guidelines for the Implementation of the World Heritage Convention. The KVWHS is comprised of exceptional Architectural typologies, ensembles and urban fabric 
which illustrate the highly developed culture of the Kathmandu Valley which reached an apogee between 1500 and $1800 \mathrm{AD}$. The KVWHS is a testimony to the unique "Newari Culture". The cultural traditions of the multi-ethnic people who settled in the remote Himalayan valley over the past two millennia, referred to as the Newars, is manifested in the unique urban society which boasts one of the most highly developed craftsmanship of brick, timber and bronze in the world. The KVWHS is tangibly associated with the unique coexistence and amalgamation of Hinduism and Buddhism with animist rituals and Tantrism (KVWHS- Integrated Management Framework, 2007:3).

The KVWHS- Integrated Management Framework (2007:2) states that the state party to the KVWHS is represented by the Department of Archaeology, Ministry of Culture, Tourism and Civil Aviation as provided by the Ancient Monument Preservation Act 1956. The seven Monument Zones come under the jurisdiction of the local authorities as defined by the local Self Governance Act 1999. There are four Monument Zones within the Kathmandu Metropolitan City; Hanuman Dhoka Durbar Square, Swayambhu, Bauddhanath and Pashupati. The Patan Durbar Square lies within Lalitpur Sub-metropolitan City, the Bhaktapur Durbar Square within Bhaktapur Municipality and Changu Narayan within the Changu Narayan Village Development Committee. The Pashupati Area Development trust has the authority to manage the PashupatiArea as per the Pshupati Area Development Trust Act 1996. The Federation of Swayambhu Management and Conservation represents the local NGO's of the Swayambhu area. The Baudhanath Area Development Committee was established to manage the Bauddha area.

The principle Act relevant to the conservation of heritage is the Ancient Monument Preservation Act (1956). Apart from this, Ancient Monument Preservation Act 1956Fifth Amendment 1996, Local Self-Governance Act 1999, Town Development Act 1988, Pashupati Area Development Trust Act 1987, Guthi Corporation Act 1964, Building Bylaws and guidelines-1991, National building Code,1994 are the various legal provisions that directly or indirectly address heritage conservation issues (KVWHS- Integrated Management Framework, 2007:21-22).

In 2003, Kathmandu Valley was kept in the World Heritage Site in Danger list. The main reason shown by UNESCO was the loss of urban fabric. International Council on Monuments and Sites (ICOMOS) State of Conservation Report (1998) stated that the single overriding issue in protecting the integrity of the KVWHS is the control of damaging and illegal development. With few exceptions, the principal religious and public monuments are secure and require only normal maintenance. However, the traditional houses and commercial buildings, which form their essential setting are at great risk and are subjectto extreme pressure. If redevelopment continues at the present rate and is not curbed by effective 
development controls, the authenticity of the World Heritage site will be so severely damaged as to compromise its outstanding universal value (UNESCO, 1999: 3; in Maharjan, 2012:88-89).

Maharjan (2012:90-91)also adds that from 1993, in every convention, the World Heritage Committee repetitively recommended putting Kathmandu Valley World Heritage Sites (KVWHS) in the danger list, with some guidelines - 15 recommendations in 1993 and 55 time-bound action plans in 1998 - for their further improvement (UNESCO, 2004). Despite these, process for improvement in KVWHS was negligible. Later in 2003, it was kept in World Heritage Sites (WHS) in the danger list.

Tourism is the main important source of income for any heritage site. For Kathmandu, tourism has been the driving force behind heritage conservation, often dictating the local economy. Tourism does not just act as a source of income but also helps the heritage gain acknowledgement. The estimated income from tourist ticket sales and museum admissions for the Nepali fiscal year 2013/14 was USD $8,882,179$ out of which the tourist ticket sales collected from Hanuman Dhoka was USD 1,980,468, from Swayambhu was USD 603,055, from Boudha was USD 661,010, from Pashupatinath was USD 1,100,000, from Patan was USD 1,282,356 and from Bhaktapur and Changu Narayan was USD 3,351,213 (PDNA, 2015).

\section{Introduction to Bhaktapur}

Although there are many important destinations in Nepal, as discussed earlier, the most important and unique destinations among them are three. These model tourist destinations are: Sagarmatha National Park, Chitwan National Park and finally, Bhaktapur. Sagarmatha National Park is unique because it is the only National Park in Nepal where people reside. On contrary to this, Chitwan National Park gains its uniqueness from the mass dislocation of people that was conducted and hence no people reside in this park.

When talking about Bhaktapur, there are numerous reasons that place Bhaktapur as a unique and model tourist destination. The first reason is that Bhaktapur is a 'Living Cultural Heritage'. It is a 'Walking Museum' and an 'Open Museum' where the culture and traditions are omnipresent in every nook and corner of the city. Secondly, there is homogeneity in culture. Bhaktapur comprises a single ethnic group. Unlike Kathmandu, which has turned into a cosmopolitan where culture and lifestyle is highly polluted and Westernized, Bhaktapur boasts its Newar culture where Newars occupy nearly two-third of the total population of Bhaktapur. Thus, Bhaktapur is an ethno park where the locals maintain their sociality outside their house at open courtyard. Finally, at one time in history, Bhaktapur was the most disrtiest city. However, after the introduction of tourism and with the help of German's project, Bhaktapur became the cleanest city with age old traditions and heritage alive till this day. 
Perched on a hill at an altitude of $1,401 \mathrm{~m}$, Bhaktapur or Bhadgaon, literally the 'City of Devotees', is a major tourist attraction taking visitors back in time. This city retains the charming paved roads, red brick houses and a way of life that goes back to medieval times. The extraordinary 'Durbar Square' with its celebrated Golden Gate and extraordinary Palace of Fifty-Five windows reflects the glory days of the Malla Dynasty when art and architecture thrived in the three cities of the valley. This ancient city is also famous for pottery and woodcarving amply displayed on its three squares and windows respectively.

Located about $12 \mathrm{~km}$ east of Kathmandu in the Kathmandu Valley, Bhaktapur is known as the 'City of Devotees', the 'City of Culture', the 'Living Heritage', and 'Nepal's Cultural Gem'. Bhaktapur is filled with monuments, most terra-cotta with carved wood columns, palaces and temples with elaborate carvings, gilded roofs and open courtyards. The city is dotted with pagodas and religious shrines. Bhaktapur is one of the important medieval cities among the three cities of Kathmandu valley. The settlements in Bhaktapur have been developed in Lichchhavi period and developed as a capital city of early medieval period and as a separate state in late medieval period.

Bhaktapur, at $1,401 \mathrm{~m}$ above sea level, spreads over an area of $119 \mathrm{sq} . \mathrm{km}$. The maximum temperature is 28 degrees in April and the minimum is 0.5 degrees in January. Bhaktapur grows from a collection of villages strung along the ancient trade route between India and Tibet. The capital city of the Greater Malla Kingdom till the 15th century $\mathrm{AD}$, Bhaktapur was brought into present shape in the early 18th century. Bhaktapur has its gem in the Durbar Square - a World Heritage site listed by the UNESCO. Bhaktapur is world renowned for its elegant art, fabulous culture and indigenous life-style. For its majestic monuments, colourful festivals and the native Newars best known for their generations-old craftsmanship, the ancient city is also known as "Nepal's Cultural Capital”.

Slusser (1998:104) while describing Bhaktapur writes that the three squares of Bhaktapur and their monuments, the parts of the city fleetingly viewed by tourists, compose only a small part of the ancient town. Beyond them Bhaktapur is a warren of ancient tols, traditional Newar communities organized by caste, each with its own local deities, and each with its particular "way of the dead", the prescribed route along which its defunct residents must be borne in their passage to the cremation ghats. In all these tols, as in much of Patan and parts of Kathmandu, life throbs to rhythms very different from those heard today on New Road in the capital city.

Many Nepalese traditional style temples, Sikhara style temples, Historic Palaces, Courtyards, Mathas, Buddhist shrines and monasteries, built in the medieval period and later on, are located at the centre of Bhaktapur city. Hence, the Durbar Square is the historic core of Bhaktapur city declared as protected monument zone and enlisted 
as monument zone of Kathmandu Valley World Heritage Site. The Durbar Square suffered badly from the earthquake of 1934 A.D. before being hit again by the recent earthquake of April 2015.

Bhaktapur is also called Bhadgaon and Khwopa (in the native tongue). The population is approximately 304,651 with $87.85 \%$ Hindus and 9.18\% Buddhists. The major populations are Newar (63\%) with Chhetri, Brahmin and Tamang in the minority. The main agricultural productions are paddy, wheat, corn, pulse, millet, citrus, guava, pears, junar, haluwabed, cauliflower, peas, beans, cucumber, and pumpkin. (Source: Bhaktapur.com)

Bhaktapur is filled with Hindu and Buddhist religious sites and art. Although the population is primarily Hindu, there are nineteen Buddhist monasteries (Vihars). Bhaktapur is rich in architectural beauty with not just religious sites but also palaces and courtyards where tourists can easily spend days absorbing the traditions and culture of the Newars.

Tourists can watch potters create works of art in the Pottery Squares. Indigenous (Newar) handicrafts include paubha scroll paintings, papier-mâché masks, cotton cloth, woodcarvings, metalwork, jewelry and ceramic products, haku-patasi (black sari), black caps and Juju-dhau (yogurt). The Durbar Square, Taumadhi Square and Dattatreya Square are the main cultural heritage sites that attract numerous tourists annually. Bhaktapur's Durbar (Royal) Square was added to the list of World Heritage Sites by UNESCO in 1979 A.D. Many festivals are celebrated throughout the year to mark the seasons, pay tribute to gods, and remember historical and legendary events.

Various fares/ festivals are celebrated in Bhaktapur which include BisketJatra, BhotoJatra, IndraJatra, Nepal Sambat, Buddha Jayanti, Dashain, Tihar, YomahriPunhi, TamuLhosar, Saki-manaaPunhi, GaiJatra, Krishna Janmasthami, Teej, Janai Purnima, Naag Panchami, GhantaMangal, Ram Nawami, ChaiteDashain, Holi, Shivaratri, Shree Panchami, Pishach Chaturdashi, Byaja Chaturdashi, etc. Various cultural dances are also performed in Bhaktapur such as Aarati Dance, JyapuJyapuni Dance, Dhimen Pyakhan, Bhairav Dance, Astamatrika Dance, Bhasmasur Dance, KhyaPyakhan, Kumari Dance, BhuranJya, etc. (Source: Bhaktapur Tourism Development Committee).

The economy of Bhaktapur is mainly agricultural. However, the non-agricultural economy consists of craftsmen, bakers, butchers, collectors, grinders of herbal medicines, spinners and weavers, blacksmiths, metal image casters, city craftsmenmasons, carpenters, wood carvers, stone carvers, specialized performers and providers of services- musicians, ritual dancers, barbers, medical specialists of various types, various kinds of priests and ritual specialists, mid wives, cutters of umbilical cords, astrologers, tailors, fishermen, sweepers, etc. (Levy, 1992). 
Levy (1992) also gives an account of the shrines and temples of Bhaktapur which are distributed among various dieties. This includes 29 shrines and temples of Vishnu, 28 of Shiva, 24 of Ganesh, 3 of Saraswati, 3 of Bhimsens, 2 of Nataraja, 2 of Hanuman, 2 of Krishna, 3 of Ram with his consort Sita, 1 of Bhairava, 2 of Jagannatha, 1 of Dattatreya and 26 of a group of dangerous or Tantric goddesses that include some fourteen major named forms.

The entry points to Bhaktapur are Khauma, Thulo Byasi, Sano Byasi, Mahakali, Bekhal, Mool Dhoka, Kamal Binayak, Chyamasimha, Hanumanghat, Bhelukhel, Ram Mandir, Bharuvachow, Barahi, Bansha Gopal. The major areas of Bhaktapur that are of great cultural and touristic value are the Bhaktapur Durbar Square, the Taumadhi Square, the Dattatreya Square, the Pottery Square and the various Buddhist Monuments. The Newar culture itself draws in many tourists each year. Thus, tourists are drawn in by the tangible as well as the intangible heritage of Bhaktapur. The Newari drinks and foods also represent the Newar culture of Bhaktapur. These include: Ayla, Thwon,Dhau, Momocha, Choila, Samaybaji, Syabaji, Chunla, Paula, Senlamu, Baji, Chatanmari, Gwaramari, Yomahri, Wo, Kachila, Pukala, Sapumihcha, Kwati, Mari, etc.

Bhaktapur Durbar Square is a conglomeration of pagoda and shikhara-style temples grouped around a fifty-five window palace of brick and wood. The square is one of the most charming architectural showpieces of the Valley as it highlights the ancient arts of Nepal. The golden effigies of kings perched on the top of stone monoliths, the guardian deities looking out from their sanctuaries, the wood carvings in every place-struts, lintels, uprights, tympanums, gateways and windows-all seem to form a well-orchestrated symphony. The main items of interest in the Durbar Square are the 55 window palace, the National Art Museum, the Golden Gate at the entrance to the Taleju Temple, the Big Bell built by Ranjit Malla in the $18^{\text {th }}$ century, the Yaksheswor Mahadev Temple built by Yaksha Malla in the 15th century, the Vatsala Temple, Phasi Dega, and many stone, wooden and metal masterpieces.

Taumadhi is the next important square of the city with multi-roofed and rectangular temples exhibiting best craftsmanship of stone sculptures, stone spouts, traditional water tank and wood carving. The Nyatapola Temple, Pottery Square, Bhairavnath Temple, Tilmahadev Temple etc., are the major monuments of the square. Nyatapola is Nepal's tallest five-storey pagoda temple built in 1702 by King Bhupatindra Malla dedicated to Goddess Laxmi.

Bhaktapur is famous for its traditional pottery industry. The age old craft has survived the calls for modernization and today it enhances Bhaktapur' value as a city of Heritage. Located at the dark, damp alleys beckon on either side of the main road, the most promising destination in this area- Potter's square, a sloping open space south west of Taumadhi Tol. Walking towards Bolachhen/ Talakwa, better known as 
the town's Potter's square, the streets are lined with small shops selling innumerable items produced in baked clay and the pavements are filled with black clay items drying in the strong sunlight. Within the Talakwa pottery square, two important temples of a solid- brick Vishnu temple and the double roofed Jeth Ganesh can be seen in a very traditional way. On the northern side of the square a small hillock is topped by a Ganesh shrine and a Shady papal tree. Guided by skilled hands, the cones of wet black mud are shaped and smoothed into yoghurt bowls, washbasins, giant grain storage jars and tiny oil lamps. With the exception of the planting and harvesting season, the potters of Bhaktapur are always busy shaping the natural clay into any imaginable shape. The craftsmen have passed this technique down from generation to generation and even today, the majority uses traditional techniques.

It is the oldest part of the city. The square take sits name from Dattatreya Temple and the ornate monasteries known as Maths. Dattatreya, the oldest temple of the city, Bhimsen Temple, water spouts, peacock window and Maths are the major attractions of the square. Other than the Dattatreya Temple itself the important attractions are the Bhisin Dega, Pujari Math, the Wood-carving Museum, the Bronze and Brass Museum, Salan Ganesh, Nava Durga Temple, Wakupati Narayan Temple, etc.

\section{Tourism in Bhaktapur}

Bhaktapur is not just the cleanest district in the valley, it is said to be the "living heritage" with a strong 'sense of sacrality', a strong 'sense of community', a strong 'sense of historicity' and a strong 'sense of serenity' where the residents understand the symbolic importance and also the importance of preservation of their heritage (Silva, 2015). This is also a reason that attracts many tourists towards Bhaktapur.

Bhaktapur depends on tourism for about $60 \%$ of its revenues. Since the downfall of the Rana-Regime, Nepal has opened up to the outside world and has observed gradual growth in incoming cultural tourists. Most of them have visited Bhaktapur as packaged tours organized by travel agencies in Kathmandu. Many tourism entrepreneurs established souvenir shops in Bhaktapur from 1964 onwards and by 1990 most of them had financially sound businesses. In 1995 the Bhaktapur Municipality started imposing an entrance fee of USD 5 for foreigners of non - SAARC countries to enter the core city area. Travel agents and tour operators opposed the decision, as this added more cost on their tours, whereas tourism entrepreneurs opposed this very decision, based on fear of a decrease of foreign visitors and business. This, however, was not the case and in order to have an organization representing and advocating the interests of tourism related businesses, associated with the overall tourism development, the Bhaktapur Tourism Development Committee (BTDC)) was established by a group of enthusiastic tourism entrepreneurs in 1997 (Source: Bhaktapur Tourism Development Committee). 
According to the Tourist Information Centre of Bhaktapur Municipality, Bhaktapur received a total of 301,012 tourists in the year 2071 with maximum tourists from China and India followed by tourists from France, America, Germany, Spain and many other tourists arriving from different parts of the world. Bhaktapur municipality collects Rs 1500 from non-SAARC tourists and NPRs 500 from tourists from SAARC region. The museum entry fee is Rs 150 for foreign citizen, NPRs 50 for SAARC citizen and NPRs 25 for Nepali citizen. A total of 2,64,542 tourists visited Bhaktapur district in 2013. According to Bhaktapur Municipality, 1,18,081 tourists from SAARC countries and 1,46,461 tourists from other countries visited the district in the past year. The number of tourists visiting the district increased by five percent in 2013 in comparison to 2012. A total of 2,52,261 tourists had visited the district in 2012. The Bhaktapur Municipality had collected NPRs 172.915 million from tourists in revenue in 2013.

Heritage tourism is specifically important to Bhaktapur. This is proved by a survey conducted by Bhaktapur Tourism Development Committee (BTDC) in 2008. The survey conducted upon 209 tourists showed the major travel motivation that drives the tourists to visit Bhaktapur. Out of the total tourists $32 \%$ were found to be drawn in by the World Heritage Sites, $30 \%$ by the local culture and traditions, $29 \%$ by the local people and their lifestyle and the rest $7 \%$ travelled for other purposes. If this survey is to be focused, then heritage (tangible as well as intangible) is the major source that motivates tourists to visit Bhaktapur.

Tourism in Bhaktapur has not just generated revenues for the Government. It has also promoted entrepreneurship, generating opportunities for tourist guides, hoteliers, staffs working in hotels and restaurants, lodges, local artisans, local art and crafts sellers and majority of the people of Bhaktapur. Tourism in Bhaktapur has opened up various opportunities for the locals ranging from creation of market for local traditional crafts to part -time jobs for students. Tourism has generated a lot of direct and secondary employments, and stimulated the local economy through income and employment multiplier effect. In addition to this, the revenues collected from tourism in Bhaktapur have helped to open and sustain six colleges in Bhakatapur. Four of these colleges include, Khwopa Engineering College, Khwopa College of Engineering, Khwopa Polytechnic Institute and Khwopa College.

Tourism in Bhaktapur has brought upon various economic and socio-cultural impacts. As Bhaktapur is becoming more popular for tourists, people are more attracted towards the tourism industry by opening hotels, restaurants, handicraft shops, etc. many people are also getting employed as guides and street hawkers. Tourism is Bhaktapur has become a job oriented industry that has helped many people to be employed and earn their living. Even the farming industries such as such as vegetable 
farming, fish farming, livestock farming and fruit farming are being highly benefitted by tourism. Tourism has furthermore, increased the price of land, increased the rental opportunities of land and buildings, increased the opportunity of selling local culture to the tourists and also increased the opportunities of opening businesses. Tourism has also helped the heritage of Bhaktapur get a greater acknowledgement and hence a better opportunity of heritage conservation.

Inspite of these advantages, tourism has also brought upon some negative impacts. Shrestha (2014) analyses that while tourism does help to build up a community infrastructure and also provides the opportunities for cultural exchange developing international peace, friendship and understanding, it also causes the introduction of conflicting ideas and styles into the community where sharing the important community resources with outsiders becomes inevitable.

Kunwar (2012:44) argues one must accept that tourism is neither a blessing nor blight, neither poison nor panacea. Tourism can bring great benefits, but it can also bring social problems. There are a number of problems that can be created by tourism which includes creating excess demand for resources, causing inflation, creating social problems, degrading the natural physical environment and the cultural environment, resulting in unbalanced economic development, increasing the incidence of crime, prostitution and gambling, threating the family structure and commercializing culture, religion and arts.

Despite the negative repercussions that tourism can bring, the positive advantages are many and as such development of tourism is a must. Heritage tourism for Bhaktapur is further a unique and most identifying form of tourism as E. Alexander Powell, an American tourist who had been to various Asian countries, mentions that it was worth making a journey half way round the globe to see the Bhaktapur Durbar Square only.

\section{Impact of the Earthquake on Heritage Tourism in Bhaktapur}

Bhaktapur has been categorized as a crisis hit district by the Ministry of Home Affairs. Tourism is the next major economic source after agriculture in Bhaktapur. Bhaktapur depends on tourism for almost $60 \%$ of its direct financial resources. The per capita disaster effects, per person in Bhaktapur is NPRs 78,770. According to PDNA, the estimated revenues from ticket sales and museum admissions in Bhaktapur in the fiscal year 2013/14 was NPRs 325,121,320. Now, due to the earthquake, the total damage to physical assets and infrastructures in Bhaktapur amounts to USD $5,330,000$. The impact on livelihood estimated at $10 \%$ of damage amounts to USD 533,000 . The losses from tourist ticket sales amounts to USD 2,808,849 and the cost of recovery and reconstruction amounts to USD 6,396,000. About NPRs 69,74,574 has been spent by Bhaktapur Municipality for cleaning the debris only (PDNA, 2015). 
The impact of the recent earthquake is evident in the various facets of heritage tourism. These include the tangible and the intangible heritage, service delivery, tourism itself, local economy and the cultural industries. The earthquake has, however, opened up some new opportunities as well. These have been discussed below:

\section{Effects on Tangible Cultural Heritage}

According to the preliminary report of Department of Archaeology, seven hundred and forty five monuments of twenty districts have been affected by the earthquake. Out of them, one hundred and thirty three monuments have completely collapsed, ninety five monuments have partially collapsed and five hundred seventeen monuments are partly damaged. The report revealed that four hundred forty four monuments have been affected within the Kathmandu Valley only, out of which eighty three monuments have collapsed from the base.

The preliminary list also states that five historic monuments have been collapsed and fourteen monuments have been partially damaged out of one hundred thirty nine classified monuments in Bhaktapur Durbar Square Monument Zone. Out of the numerous monuments of Bhaktapur district, 43 monuments are partially damaged and 19 monuments have completely collapsed. The report also adds that the earthquake has completely destroyed 25-30 traditional houses which belonged to the protective Monument Zone (DoA, 2015).

DoA (2015) also states that among the collapsed temples, Batsleswori is one of the gorgeous temples of Bhaktapur, dedicated to Durga and built in Shikhara style on a stone pilth by JitamitraMallain 16th century AD. Another collapsed temple is Shilu Mahadev temple known as FasiDega. The temple was rebuilt from its base after destruction in 1934 AD. One more Shikhara style temple known as Kedarnath temple built during the time of King BhupatindraMallla is also damaged in its upper part.

Apart from this, Bhaktapur Municipality had also conducted a survey upon the heritages destroyed by the earthquake. The preliminary report of the Municipality states that a total of forty nine built heritages have been partially destroyed which does not just include temples and monasteries but also includes the secular buildings such as Patis and Ghats. A total of sixty seven built heritages need to be reconstructed completely and have been termed as 'Purna Ayogya'. Some of the important heritages that are rendered useless are Phasi Dega, Vatsala Temple, Prasannnashil Aagamachhen, Taleju Temple, Brahmayani Temple, Swet Bhairav Temple, Pujari Math, etc. Ten temples of Hanumanghat area have also completely collapsed. Similarly, out of the three museums, The National Art Museum has also suffered partial damage where the outer façade of the museum has sustained major cracks. Bhaktapur Municipality has estimated that the total loss to cultural heritage due to the earthquake amounts to twenty nine crores thirty two lakhs Nepali Rupees (Bhaktapur Municipality). 
The fact worth considering is that this is just the preliminary report and hence, the destruction caused by the earthquake to the cultural heritages in Bhaktapur can have a much wider and deeper impact physically, economically, environmentally and socially. While the preliminary report shows the destruction of 116 heritage buildings, the Municipality's revised update shows more than 145 archaeological structures related to cultural heritage need reconstruction.

\section{Effects on Intangible Cultural Heritage}

The intangible cultural aspects of worship, rituals and festivals are severely interrupted at temples that have completely collapsed. Loss of important tangible heritage is interrelated with loss of intangible heritage and identity due to which loss of intangible heritage could be treated in parallel with loss of tangible heritage. Significant economic losses have incurred in communities that rely on revenue generated with the interruption of annual ritual activities. While some structures have withstood the quake, many are unsafe for devotees to use and conduct rituals and commune to the deities housed inside. Ritual performances and religious dances associated with the temples that have been destroyed have been severely curtailed leading to a potential loss of this intangible heritage.

Many public rest houses (patis) have also collapsed or have been badly damaged. The patis like Yosi Pati, Bhuju Pati, Bhramayani Deep Pati, etc. have been rendered completely unable to be used and many other patis like Galasi Bhajan Pati, Lakulachhen Pati, Indrayani Pith Pati, etc. have suffered huge damages as well. These community structures provide a meeting place for people of all generations to share news and stories as well as provide a common place for the locals to sing prayer songs. Damage to these structures could mean a loss in the continuation of oral narratives which is intrinsically linked to community culture in Bhaktapur as well as in Nepal as a whole.

\section{Effects on service delivery and access to goods and services}

The destruction of buildings had caused the closing of cultural institutions such as libraries, museums and archives as well as places of religious worship, such as temples and monasteries. The closing of Government offices and institutions, such as cultural centres and museums, has also slowed down the implementation of ongoing restoration projects. The world Heritage Zone of Bhaktapur had been reopened to public since June 15, 2015. Bhaktapur was the first to reopen its heritage site for tourists to visit after the quake. However, the unsafe structures still remain to be dismantled and unsafe areas fenced off properly in order to provide a safe environment for visitors.

\section{Effects on cultural industries}

According to Cottage and Small Scale Industries of Bhaktapur, Bhaktapur has a total of 124 handicraft industries producing wooden crafts, stone sculptures, bronze 
statues, metal sculptures, paper, silk, etc. Bhaktapur also houses a total of 48 Thanka industries. While none of these industries have come to officially report closing of their industry due to the earthquake, Bhaktapur Gharelutatha Sanaa Udhyog Sangh (Bhaktapur Association of Cottage and Small Scale Industries), an association of 242 cottage and small scale industries of Bhaktapur has reported that 58 industries related to the association have been destroyed completely and 33 have been destroyed partially killing four people and injuring nine. These industries however, do not just include the handicraft and the Thanka industry.

There may however be some positive effects in the knowledge, transmission and implementation of traditional craftsmanship, as more craftsmen will be needed to restore the many historic houses, temples and monuments that were damaged. Opportunities presented on such a large scalecould revitalize traditional crafts, such as traditional masonry techniques, wood-carving, stone-carving and metal repoussé techniques. As Nepal does not have enough craftsmen to handle the current need, a small number of local master-craftsmen could take lead in transmitting traditional knowledge to the next generation, and document the same to contribute to retention of knowledge economy that values cultural heritage. However, as most of the buildings that collapsed were older structures built using traditional materials, following the earthquake, a concern that is widely shared is that local people may view traditional materials and craftsmanship as "unsafe" and would be more inclined towards accepting concrete structures as a safer alternative (PDNA, 2015).

\section{Effects on Tourism}

According to the Tourist Information Centre of Bhaktapur Municipality, Bhaktapur received a total of 301,012 tourists in the year 2071. However, in the aftermath of the quake, tourism in Bhaktapur decreased drastically. Bhaktapur received 6808 NonSAARC tourists in April/May 2015. The number decreased to just 11 in May/June and improved to 1117 in June/July compared to 5095 non-SAARC tourists of the previous year in June/July. Similarly, the SAARC tourist numbers in Bhaktapur was 5738 in April/May, 9 in May/June and 392 in June/July, 2015. Thus, while tourism in Bhaktapur had always been increasing except in the year 2004/05; 2014/15 received just 244,144 tourists compared to 290891 tourists in 2013/14.

The tourists' views regarding Bhaktapur however, has gained mixed reactions after the earthquake. While many tourists are still drawn in by the lush cultural heritages and living culture of Bhaktapur, many other find it very exciting to visit Bhaktapur, especially after the quake, to see how it has sustained and also to see what remains after the quake. When asked whether they feel safe and if they would visit again, many tourists replied positively as places like Bhaktapur help them escape the daily chaos of the concrete world and help them escape into a distant world that is so different from theirs. 
In this regard, Lowenthal's (1998:6; in Park, 2014:7) statement becomes lively and full of explanation: 'Dismay at massive change stokes demand for heritage... Beleaguered by loss and change, we keep our bearings only by clinging to remnants of stability... Mourning past neglect, we cherish islands of security in seas of change'.

\section{Effects on Local Economy}

Integrated Management Framework (2007:32) states that the local economy in and around the Monument Zones is geared towards tourism. The Monument zones cater to varying degrees of visitors. Squares are city centres and are therefore also vibrant areas for the local economy. The recent earthquake has however taken its toll upon the local economy in and around the Monument Zone in Bhaktapur. The research conducted by the author showed that the business of the souvenir shops have seen great depression after the quake. Many souvenir shops selling wooden artifacts have suffered damages to their shops due to the earthquake. Many add that their income has decreased $50-80 \%$ as compared to a no-earthquake scenario. The sellers worry about the negligible number of tourists visiting these days causing their economy to follow a downward slope. Similarly, the souvenir shops selling metal and bronze sculptures also have a similar story to tell. Here as well, many shops have suffered physical as well as economical damage. Their income has decreased by more than 50\%. Many shops in the Pottery Square have also witnessed losses of similar manner.

Restaurants and hotels are left with damages as well as lesser tourists to cater their services to.The quake damaged 111 hotels in Bhaktapur causing a loss of USD18.8 million (My Republica, 8 June, 2015).

\section{New Opportunities}

Faulkner \& Vilukov (2001; in Kunwar, 2016: 17) state that despite the negativity that crises generate, crises are not only considered negatively as some researcher suggest positive effect of crises such as stimuli to innovation or the recognition of new markets. Holmes (2003; in Campiranon \& Scott, 2007: 151) thus emphasize that at the heart of every crisis lies tremendous opportunity, and perhaps this is why the Chinese word for crisis is surprisingly composed of two symbols meaning 'danger' and 'opportunity' (Kunwar, 2016: 17).

Apart for increased publicity of Nepal and the positive benefits upon the traditional crafts as discussed earlier, Maharjan (2015) states that the recent earthquake has also left some other positive repercussions. The damaged temples have now drawn in many researchers regarding how the monuments have been built and how they can be repaired. Also many opportunities of researches have opened up related to cause of such extensive damage and how such structures can be strengthened to make them earthquake resistant. Even the students from neighboring country have visited 
durbar squares to study the monuments and the construction technology. Many conservationists believe that a new door has been opened for the development and conservation of our centuries old sites. Because of the earthquake, internationally, our heritage sites have become popular and many donor agencies are willing to donate funds to conserve our heritage sites. Nepal Government has already put aside NPRs 2 billion for the restoration of monuments.

\section{Recovering Heritage Tourism}

Mair et al. (2014) define post-disaster recovery as the development and implementation of strategies and actions to bring the destination back to normal (preevent) condition or an improved state. Andrew Jones, vice-chairman of the Pacific Asia Travel Association (PATA) recalls; 'I have visited Nepal several times. My first impression towards Nepal after the April 25 deadly earthquake was that the country had been devastated. The international media reports showed that everything had been destroyed. But when I arrived here, it was much better than I had anticipated. To be honest, I didn't have any problems visiting the country. No dangers at all. In general, I don't find Nepal unsafe to visit. There are many places in Nepal that have escaped the disaster, and there are many places to visit. But businesses are not normal yet. Like me, visitors need to know the reality that many places are safe to visit. We are not actually saying that the situation has become normal and come from tomorrow. But it's going to be on the right track soon' (The Kathmandu Post, 5 May, 2015). While such opinion leaders can definitely help recover tourism by minimizing the threat being felt in some source markets to visit Nepal, the fact worth considering as put forward by Beirman (2003) is that crises such as natural disasters are one of the highly publicized localized crisis which often deter tourists from visiting the entire destination.

Tourism has time and again suffered the wrath of crisis, be it natural or man-made, time and again in the history of Nepal's tourism itself where we have encountered drastic decrease in the influx of inbound tourism. Thus, for the recovery of heritage tourism, focus now has to be given to heritage reconstruction as it is the immediate need and also long term strategic marketing can help properly address the concerns as well as strengthen the tourism industry.

\section{Heritage Reconstruction}

In Bhaktapur, the Archaeological Department under the Government of Nepal and the Bhaktapur Municipality are responsible for the preservation, maintenance, repair and renovation of the heritage sites. Bhakatapur Municipality utilizes NPRs 40 million annually to conserve the cultural heritage site of Bhaktapur. After the earthquake, the Government has focused more upon the issue of reconstruction. The Government has allocated the task of reconstruction of cultural heritages after the 
earthquake to the National Reconstruction Authority (NRA) but the NRA has still not finalized its plans of reconstruction.

Thus, the reconstruction of heritage sites is still just limited to paper and drawings. In case of Bhaktapur, the reconstruction of the destroyed heritages will be done through German assistance as well. Bhaktapur Municipality has not yet received any budget for reconstruction. However, the Municipality has been doing a detailed survey of the destroyed cultural heritages, estimated the total monetary loss caused by the destruction of the cultural heritage and has also estimated the amount needed for reconstruction. Bhaktapur Municipality, as such, has estimated that a total of NPRs 29 crores and 32 lakhs will be needed for the reconstruction of the destroyed cultural heritages. However, this is still not the finalized report. The Himalayan Times (5 November, 2015) stated that the Department of Archaeology, Guthi Sansthan and German Development Bank signed an agreement on reconstructing and restoring Pujari Math (Hindu priests' houses) at Tachapal Tole, Bhaktapur on 4 November, 2015.

NRA launched a national reconstruction campaign on January 16, marking 1934's devastating earthquake anniversary. And reconstruction works will begin on April 24 coinciding with the first anniversary of April earthquake. President Bhandari laid the foundation stone at the Ranipokhari temple to symbolize the start of reconstruction of public heritage sites and the prime minister unveiled a map of the reconstruction master plan for the Bungmati area the same day.

Despite this, ironically, My Republica (25 January, 2016) writes that the newlyformed National Reconstruction Authority (NRA) has been working at a snail's pace if a month-long work of the authority is any indication. Though the prime minister and top officials of the NRA had earlier announced that it would work on a warfooting, the NRA has utterly failed to gather momentum in its work despite the fact that the autonomous body, authorized by a parliamentarian act, exercises full authority in decision making on its own.

On January 11, the NRA's directive committee headed by the prime minister passed over NPRs 290 million budget for the NRA. With this, it was widely expected that the authority would expedite its task as claimed by the prime minister, top government officials and the $\mathrm{CEO}$ himself. Over two weeks have elapsed since then but the CEO has failed to recruit officials for its central office. The authority has not been able to set up its seven regional offices in the quake-affected districts in lack of staff though it decided to establish the offices on January 13. The regional offices are supposed to monitor and facilitate all the tasks related to the reconstruction at the ground level. The NRA has failed to exercise its power and work as an effective autonomous body, which is its main objective. Government officials say that the NRA's working and decision making style hasn't been any different than the usual and 
lengthy bureaucratic works at the ministries. NRA had however stated earlier that the reconstruction of cultural heritages could start from April, 2016.

Apart from this, International donors have pledged more than USD 4 billion (approximately NPRs 400 billion) and NPRs 74 billion that the government has allocated for the reconstruction projects remains unspent, while tens of thousands of people are taking shelter under flimsy tents in extreme cold. Advisory Council members have been briefed that the authority was in a position to mobilize around USD 200 million for reconstruction.

Thus, due to these bureaucratic difficulties, Bhaktapur municipality has still just limited its works to cleaning of the debris.

A six-year recovery period, requiring on average USD 34 million per year is proposed by the PDNA for the restoration and reconstruction of all damaged and collapsed buildings including refurbishment of cultural institutions and museums. But the task of reconstruction can be much lengthy and complicated.

In an interview, Shaphalya Amatya, former Director General of Department of Archeology who has written a number of books on various cultural and heritage sites of Nepal emphasized, "We need to start our work only after carrying out an intense study. Some temples are completely ruined and some damaged partially. The process of reconstruction is very lengthy as you need to have drawings to the scale and documentation. One needs to see whether the drawings are perfect on the basis of structural engineering.There is the need to make a cost estimate following the drawings. The situations of 1934 and now are different. The population of Kathmandu was much smaller and there was enough wood available around Kathmandu. There were enough endogenous masons, laborers, carpenters, painters and others. The situation is different now. You have to go far away to bring the brick. You need to train the new manpower to do the complicated work to reconstruct the temples. I think it will take decades as it is not simply like rebuilding the houses. There are so many complexities involved in the construction of temples. There are so many nitty-gritties during the assembly of the temples. You need to make special bricks for temples and there is a need of special craftsmen, carpenters, laborers, artists and architects" (New Spotlight News Magazine, 8 May, 2015).

\section{Tourism Restoration}

Similarly, for tourism recovery, Bhaktapur has reopened its cultural heritages to tourists from June 15. The reopening of the World Heritage Site gives a positive message to the world that Bhaktapur is back in business and waiting for tourists to visit them. Similarly, various events such as Gaijatra Mahotsav was conducted so as to lure in tourists by the intangible heritages of Bhaktapur at a time when the tangible heritages incurred huge devastation. 
Bhaktapur had also formulated some planned activities related to sustainable tourism before the earthquake. These include formulation of Tourism Master Plan, development of home stay activities in the possible VDC's of Bhaktapur, skill enhancement training for women, Community awareness program and tourism promotion project in Changu Narayan, culture promotion through cultural program, development of short hiking and trekking trial and development of agro-based tourism (Bhaktapur Municipality). The past activities related to sustainable tourism includes Bhaktapur Night, environment campaign, celebration of World Tourism Day, organization of Multi-stakeholders' conference on the sustainable tourism development of Bhaktapur district, short hiking trail development on the surrounding villages, service quality enhancement training and house-keeping training.

The District Development Committee of Bhaktapur has also published its plans for tourism development and management until 2017/18. The focus as such will be upon Rural Tourism, Meeting, Incentive, Conference and exhibition (MICE) Tourism, Education and Research Tourism, Pleasure, Recreation and Entertainment and Health, Spa and Meditation tourism. Similarly, the DDC has also formulated priority programs for 2017-2021 which includes Diversification of Tourism Products and Trekking Routes, Consolidation and Elaboration of Tourism Activities, InterDistrict Tourism Development and Promotion of Cultural and Pilgrimage Tourism.

In the national level, to cope with the tourism crisis, the Pacific Asia Travel Association (PATA) submitted a Nepal Tourism Rapid Recovery Taskforce Report and Recommendations to the Nepal Tourism Board. The government has reopened most of the cultural heritages sites damaged by the earthquake including the all three former royal squares from June 15. The recently formed Tourism Recovery Committee (TRC) has been tasked with minimizing the repercussions of the earthquake in the tourism sector. Similarly, PATA and National Tourism Promotion Committee (NTPC) unveiled a refreshed recovery strategy and plan logo that was used for the immediate $3+$ month recovery phase; 'NEPAL. BACK, ON TOP OF THE WORLD'. Also, Nepal Association of Tour and Travel Agents (NATTA) had announced familiarization tours to Chitwan and Pokhara for international media and tour operators to let the world know the realities in and around the coveted destinations (MoCTCA, 2015).

Kunwar (2015) writes that within a week of the earthquake, 24 International Airlines had decreased their 294 flights to 191 flights and the decreased flights were not fixed to take off till October. Likewise, some tourism generating countries issued travel advisories by considering Nepal as a vulnerable destination where tourists were not likely to be safe and secure. To deal with these hindrances, Nepal has adopted the practices of crisis management. Nepal has not just sought to catch the eyes of the world by unveiling a plan logo but has also hosted familiarization trips from China. China also happens to be the largest tourism generating country for Bhaktapur. Similarly, 
seventeen International and five Nepali mountaineers were felicitated and honored as Goodwill Ambassadors for Nepal. The Nepal tourism Board's official website also give an up-to-date view of the current scenario to the tourists. In August the NTB also completed a historical destination promotion program in three major cities of Australia- Sydney, Melbourne and Brisbane as a part of post-earthquake tourism recovery plan.

Incentive Holidays announced the launch of the first ever smart travel companion app for travelers named "Gonepalholiday", and a travel magazine named "Gonepal E-magazine”, describing Nepal's tourism status post-earthquake. Gonepalholiday improves travelers' in-trip experience by displaying a contextual, actionable view of the itinerary of Nepal's popular destinations, hotels, trekking, and maps, including other travel and tourism related information. Travelers may download Gonepalholiday on smartphones running both Android and iPhone operating systems (New Spotlight News Magazine, 12 June, 2015).

Post-earthquake, reportedly $80 \%$ of hotel reservations had been cancelled. While hotels in the capital still had a relatively good occupancy rate, the rooms were occupied by foreign rescue teams, media personnel and members of international agencies. For tourism recovery, the Post-Disaster Needs Assessment Report has urged the Government to announce 2017 and 2018 as Nepal Tourism Year to assure visitors that reconstruction and rehabilitation will be completed by then.

Good coordination among the key stakeholders is needed to ensure that foreign tourists perceive Nepal as a safe destination to visit. As the Nepal Tourism Board and the private sector have been spending NPRs 2.20 billion annually on tourism marketing and promotion during normal times, the outlay has to be increased multiple fold to revive the market. Also, there is a need to re-build and re-brand the image of tourism, and significant efforts and resources will be required to do this. Despite the overall estimated damage and losses, the tourism industry remains resilient and optimistic about executing a turn-around in the medium to the long term. The sector is poised to build back better with concerted efforts from all the stakeholders and support from the Government. However, the efforts need to target the global tourism market and convince potential visitors to come to Nepal besides providing assistance to the affected rural and urban tourism entrepreneurs (PDNA, 2015).

\section{Response of academic institutions to earthquake in Bhaktapur}

Bhaktapur Municipality has contributed a lot towards establishing educational institutions in Bhaktapur where six colleges have been established by the revenues collected from tourism alone. Many academic institutions, as such, have played their part to address the recent earthquake and the destruction it caused. Khwopa Engineering College (KhEC) is one such academic institution. 
KhEC is Nepal's first community-based engineering college, undertaken by Bhaktapur Municipality. After the earthquake, many teaching staffs and students went to observe the destruction caused by the earthquake. The college further conducted various training programs related to construction. The programs included masonry training conducted in two levels. This training program reached out to almost 250 people. Similarly, trainings were also provided to around $70-80$ people which was related to traditional style of carpentry and masonry training.

On the $18^{\text {th }}$ Earthquake Safety Day on January 16, the institution hosted various workshops and seminars related to the earthquake in Bhaktapur Durbar Square. Furthermore, the college has also planned to conduct an international seminar related to the earthquake in April, 2016.

In addition to this, a team of 14 students and two professors from Namseoul University of South Korea is preparing to provide Sand Play Therapy to the quake survivors of Bhaktapur from January 27. The therapy aims to alleviate the trauma that the quake survivors experienced during the April 25 earthquake. The therapy will be given to school children and other quake survivors at Bhaktapur-based BidhyaArjan Boarding School. Professors from Namseoul University accompanied by Srijana Thapa, who is an assistant professor at the Department of Child Welfare in the varsity, said the therapy was being provided to the quake survivors for the second time in Bhaktapur and Lalitpur. The team is also planning to organize a workshop and provide a 50-hour training of Sand Play Therapy here in Nepal for those interested (The Himalayan Times, 26 January, 2016).

\section{Conclusion}

Heritage in Nepal is deeply connected to the nation's pride, the people's souls, belief and identity. Culture and heritage set up a distinct image of Nepal in the world. The earthquake of 2015 brought about huge loss to the heritages of Nepal, many of which identify Nepal in the outside world. The Post-Disaster Needs Assessment Report envisages a long-term recovery plan to restore the destroyed structures based on the principles of "building back better". Further, tourism during the reconstruction period would continue to benefit local businesses such as hotels, restaurants and craft stores. But, the bureaucratic difficulties are many. Though tourism has seen a slight upsurge in the aftermath of the quake, heritage reconstruction still remains present only on papers. In such a situation, heritage tourism might surely be on a halt and as such, many places such as Bhaktapur, depending on heritage tourism might suffer bitterly. The good news is that, the earthquake has also generated some publicity to Nepal, where many tourists are coming to see what is left after the earthquake.

On the grim side, the Government has still not been able to substantially start the reconstruction process. But, on the bright side, many citizen initiatives for 
reconstruction have kept the hopes of the people and the country alive. For instance, locals of Pilachhen in Lalitpur are ready to set the wheels of reconstruction works in motion soon as a part of citizen-led initiative to rebuild a historical settlement devastated by earthquakes of April and May. The reconstruction works, however, are not being executed by the government. Instead, around 10,000 locals and volunteers are taking the lead to rebuild the settlement.

Kunwar (2015) states that the underlying intention of a successful tourism recovery program is not merely restoring or getting back to where things were before the crisis event but to build back better for which the program needs to be designed to result into a more marketable destination and business and to improve infrastructure to the point that a similar event in the future may be less destructive. Also, the 'world's best practice' should be followed when restoring tourism destinations in crisis (Beirman, 2003). In addition to this, policy level changes are also required in the field of heritage conservation and preservation as a famous saying goes 'better preserve than repair, better repair than restore, better restore than reconstruct'.

As a living heritage, the unique architectures of Bhaktapur, the cultural festivals, dances, music, art and lifestyle have attracted many tourists both domestically as well as internationally. As such, concrete efforts are needed for cultural heritage reconstruction and conservation as well as for tourism promotion in Bhaktapur and in Nepal as a whole. Thus, there should be continued collective efforts from the Government as well as from the private sectors to eliminate fear among potential incoming tourists regarding the safety of the country and also regarding the availability of tourism products. The private sector can focus upon disaster tourism during the reconstruction phase where packages can be designed with a combination of earthquake hit tourist sites and unharmed tourist destinations. Tour guides can be trained to provide narratives exhibiting the resilience of the people and the country. This will not only add value to the experience of the tourists but will also draw a different set of tourists leading tourism to generate revenues that can in turn provide substantial help for the process of reconstruction as well.

Bhaktapur is a unique tourist destination in Nepal being a 'Living Heritage', an 'Ethno park' and the 'Cleanest City'. As shown in the survey of BTDC, almost all tourists in Bhaktapur come to see the cultural heritage. However, crisis creates a significant challenge for marketing a destination. Thus, for effective promotion after a crisis, the destination should be positioned positively in the minds of the consumers. This can be done through a unique and appealing destination image. The study of many researchers has shown that the more positive the destination image is, the higher is the tourist satisfaction. Satisfaction, in turn, also affects future intention behavior. Hui et al. (2007; in Moreira et al., 2014: 96) in their study showed 
that satisfied travellers are willing to choose the same destination again in the future and are also willing to refer the destination to their friends and relatives. Wang and Hsu (2010; in Moreira et al., 2014: 96) found the mediating effect of overall satisfaction on the relationship between destination image and behavioral intention. Thus, Bhaktapur has to be protected and promoted with a strategic and appealing destination image that focuses upon the cultural heritages which will not just satisfy the tourists but will also influence their behavioral intention to visit the destination again.

\section{Acknowledgement}

We would like to thank Ram Govinda Shrestha of the Heritage Department of Bhaktapur Municipality, Suresh Tamrakar of Tourist Information Centre, Bhaktapur, Narayan Bohora of Department of Archaeology, Kathmandu, Kamal Niroula of Cottage and Small Scale Industries, Bhaktapur and Shiva Krishna Koju of Khwopa Engineering College, Bhaktapur for their cooperation during fieldwork.

\section{References}

Ames, D. L. \& Hamroun, Z. (2011). Principles of Architectural Preservation. In King, T. F. (ed.) A Companion to Cultural Resource Management (pp. 29-53), UK: WileyBlackwell.

Apostolakis, A. (2003). The Convergence Process in Heritage Tourism. Annals of Tourism Research, 30(4): 795-812.

Barahi, S., Fan, R., Hung, P., Malla, P. and Yeung, R. (2011). Tourism Cluster in Nepal: Microeconomics of Competitveness. Institute for Strategy and Competitiveness, Harvard Kennedy School and Harvard Business School.

Banskota, K \& Sharma, B. (1995). Tourism for mountain community development: Case Study report on the Annapurna and Gorkha regions of Nepal. Kathmandu. International Centre for Integrated Mountain Development (ICIMOD), Centre for Environment and Resource Studies (CREST).

Beirman, D. (2003). Restoring Tourism Destination In Crisis: A Strategic Marketing Approach. Wallingford: CABI.

Beirman, D. (2003). Restoring Tourism Destination In Crisis: A Strategic Marketing Approach. Wallingford: CABI.

Beirman, D. (2003). Turkey: Izmit Earthquake, 1999.In Restoring Tourism Destinations In Crisis (pp.153-168). Wallingford: CABI

Bhaktapur Nagarpalikaka Chhetra Bhitrako Sampadaharuko Prarambhik Bhukampiya Chhyati Bivaran (A Preliminary Report of Heritage Destructions within Bhaktapur Municipality), Bhakatpur: Bhaktapur Municipality, 12 May, 2015. 
Bhaktapur Jillako Paryatan Vikas Tatha Vyavasthapan Yojana 2069/70-2073/74 (Tourism Development and management plan of Bhaktapur District 2069/702073/74), Bhaktapur: District Development Committee.

Bhele, R. S. (ed.) (2007). Bhaktapur: A Guide Book, Bhaktapur: Tourism Development Committee.

Cohen, E. (1984). The Sociology of Tourism: Approaches, Issues and Findings. Annual Review of Sociology, 10: 373-392.

Dann, G. (2000). Theoretical Advances in the Sociological Treatment of Tourism. In International Handbook of Sociology. London: Sage Publications.

DoA (2015). Kathmandu Valley World Heritage Site: Integrated Management Framework, 2007. Kathmandu: Department of Archaeology.

DoA (2015). Preliminary Report of Monuments Affected by Earthquake April 25, 2015. Kathmandu: Department of Archaeology.

Douglas, M. (1994). Risk and Blame: Essays in Cultural Theory. London: Routledge. Demographic Profile of Nepal 2013/14. Kathmandu: Mega Publication and Research Centre.

Drabek, T. E. (1995). Disaster Responses within the Tourist Industry. International Journal of Mass Emergencies and Disasters, 13 (1): 7-23.

du Cros, H. \& McKercher, B. (2015). Cultural Tourism, Second Edition. London: Routledge.

Faulkner, B. (2001). Towards a framework for tourism disaster management. Tourism Management, 22:135-147.

Fernandes, C. (2013). The Impact of Cultural Tourism on Host Communities. In Raj, R. Griffin, K. \& Morpeth, N. (eds.) Cultural Tourism, (pp.26-38) Wallingford: Cabi International.

Harvey, D.C. (2001). Heritage Pasts and Heritage Presents: temporality, meaning and the scope of heritage studies. International Journal of Heritage Studies, 7 (4): 319338.

Hoelscher, S. (2006). Heritage. MacDonald, S. (ed.) A Companion to Museum Studies (pp.198-218), Oxford: Blackwell Publishing.

Hoffmann, N. B. (2013). 'Locating' or 'dislocating' heritage and cultural tourism within the humanities. TD the Journal for Transdisciplinary Research in Shouthern Africa 9 (2): 341-356.

Huan, T. C., Beaman, J. \& Shelby, L. (2004). No-escape natural disaster: mitigating impacts on tourism. Annals of Tourism Research, 31:255-273. 
Jones, H. (2013). Entry points for developing tourism in Nepal. Centre for inclusive Growth. London, Overseas Development Institute.

Joshi, H. (2060). Nepalka Chaadparwa. Kathmandu: Sugam Printing Press.

Katriel, T.(1993). Our Future Is Where Our Past Is: Studying Heritage Museums as Ideological Performative Arenas. Communication monographs. 60 (1): 69-75.

Kunwar, R. R. (2012). Safety and Security in Tourism: A Study of Crisis and Disaster Management. Journal of Tourism and Hospitality Education. 2:58-83.

(2012). Tourists and Tourism: Science and Industry Interface. Kathmandu: Dangol Prints.

Education. 1:1-50.

(2015). Cultural tourism. Journal of Tourism and Hospitality ...(2015). Tourism and Natural Disaster: A study of Nepal's Earthquake2015. Voice of Himalaya, (1): 19-34.

...(2016). Tourism Crisis and Disaster Management. The Gaze Journal of Tourism and Hospitality. 7(1):1-36.

Kunwar, R. R. \& Limbu, B. (2015). Tourism and Earthquake: A Case Study of Nepal and Turkey. NATTA Souvenir.

Levy, R. I. (1992). Mesocosm: Hinduism and the Organization of a traditional Newar City in Nepal. Delhi: Motilal Banarasidass Publisher.

Lowenthal, D. (1985). The Past is a Foreign Country, Cambridge: Cambridge University Press.

Maharjan, S. (2015). Culture Resource Management (Assignment, Purbanchal University).

Maharjan, M. (2012). Conflict in World Heritage Sites of Kathmandu Valley: A Case Study on the Conservation of Private Houses in Three Durbar Squares. Nepal Tourism and Development Review 2:90-91.

Mali, P. (2015). Vaastukalaka Gharharu Haraaudai. Kantipur. (Nepal's National Daily Newspaper). 30 September.

Mair, J., Ritchie, B. W. \& Walters, G. (2014). Towards a research agenda for postdisaster and post-crisis recovery strategies for tourist destinations: a narrative review. Current Issues in Tourism, pp. 1-26.

Millar, S. (1989). Heritage Management for Heritage Tourism. Tourism Management.

Moratto, M. J. (2011). Archaeology of the Distant Past. In King, T. F. (ed.) A Companion to Cultural Resource Management (pp. 64-65), UK: Wiley-Blackwell. 
Moreira, P. \& Iao, C. (2014). A Longitudinal Study on the Factors of Destination Image, Destination Attraction and Destination Loyalty. International Journal of Social Sciences. 3(3): 90-112.

Murphy, P. E. \& Bayley, R. (1989). Tourism and disaster planning: Geographical Review, 79(1):36-46.

My Republica (Nepal Daily English Newspaper) (2015). New logo, slogan launched for tourism recovery, 31 August.

My Republica (Nepal Daily English Newspaper) (2016). Reconstruction Authority working at snail's pace, 25 January.

New Spotlight News Magazine (National Fortnightly) (2015). The temples should be reconstructed as earthquake resistant, May 8.

New Spotlight News Magazine (National Fortnightly News Magazine) (2015). Incentive Holiday launches Go Nepal holiday, June 12.

Nickell, D. (2011). A Displaced People's Perspective on Cultural Resource Management. In King, T. F. (ed.) A Companion to Cultural Resource Management (pp. 385-401), UK: Wiley-Blackwell.

NPC (2015). Nepal Earthquake 2015: Post-Disaster Needs Assessment: Executive Summary, Kathmandu: National Planning Commission.

NTB (2014). Nepal Tourism Statistics 2013. Kathmandu: Government of Nepal, Ministry of Culture, Tourism and Civil Aviation.

Nuryanti, W. (1996). Heritage and Postmodern Tourism. Annals of Tourism Research, 23(2):249-260

Nyaupane, G.P.(2009). Heritage Complexity and Tourism: The Case ofLumbini, Nepal. Journal of Heritage Tourism, 4(2): 157-172.

Park, H. Y. (2014). Heritage tourism. London. Routledge.

Raj, R., Griffin, K. \& Morpeth, N. (eds.) (2013). Cultural Tourism, Wallingford: Cab International.

Richards, G. \& Munsters, W. (eds.) Cultural Tourism Research Methods. Wallingford: $\mathrm{CAB}$ International.

Shrestha, D. K. (2014). Cultural Heritage Tourism in Bhaktapur, An Unpublished Master's Thesis, Submitted to the IST College Affiliated to the Salzburg University of Applied Sciences, Austria.

Silva, K. D. (2015). The Spirit of the place of Bhaktapur, Nepal. International Journal of Heritage Studies, 21:8, 820-841. 
Slusser, M. S. (1998). Nepal Mandala: A Cultural Study of the Kathmandu Valley, Vol. 1. Kathmandu: Mandala Book Point.

Smith, M., Macleod, N. \& Hart Robertson, M. (2010). Key Concepts in Tourist Studies. Los Angeles: Sage.

Stanley-Price, N. (2009). The Reconstruction of Ruins: Principles and Practice. In Richmond, A. \& Bracker, A. (eds.) Conservation: Principles, Dilemmas and Uncomfortable Truths (pp. 32-46), Amsterdam: Elsevier.

Thapa, S. (2014). Cultural Commoditization: a Study of Wooden Art in Bhaktapur, An Unpublished Master's Thesis, Submitted to the IST College Affiliated to the Salzburg University of Applied Sciences, Austria.

The Himalayan Times (Nepal English Daily Newspaper) (2015). Pujari Math of Bhaktapur to be restored, November 4.

The Himalayan Times (Nepal English Daily Newspaper (2016). Locals come together to rebuild Pilachhen in Lalitpur, January 14.

The PATA Nepal (2015). Tourism Rapid Recovery Task Force (2015). (Report and Recommendations), Kathmandu: Pacific Asia Travel Association.

Timothy, D. J. (2011). Cultural Heritage and Tourism. Toronto: Channel View Publication.

Timothy, D. J. \& Nyaupane, G. P. (eds.) (2009). Cultural Heritage and Tourism in the DevelopingWorld. London: Routledge.

Wisner, B., Blaikie, P., Cannon, T. \& Davis, I. (eds.) (2003). At Risk (Second Edition). London: Routledge.

Bhaktapur.com

lindamcmillan.com

ntb.org.np

www.btdc.com.np

www.doa.gov.np

www.nepaltourism.info

www.tourismdepartment.gov.np

www.tourism.gov.np

www.unwto.org

www.welcomenepal.com

www.wttc.org 
www.gauteng.net/cradleofhumankind/the_destination/world_heritage_sites/ heritage_tourism/ kathmandu.gov.np www.enepaltrekking.com/package/world-heritage-sites-of-nepal 